\title{
PELATIHAN KETERAMPILAN PUBLIC SPEAKING DALAM KONTEN EDUKATIF MELALUI APLIKASI TIKTOK PADA REMAJA FAM (FORUM ANAK MEDAN)
}

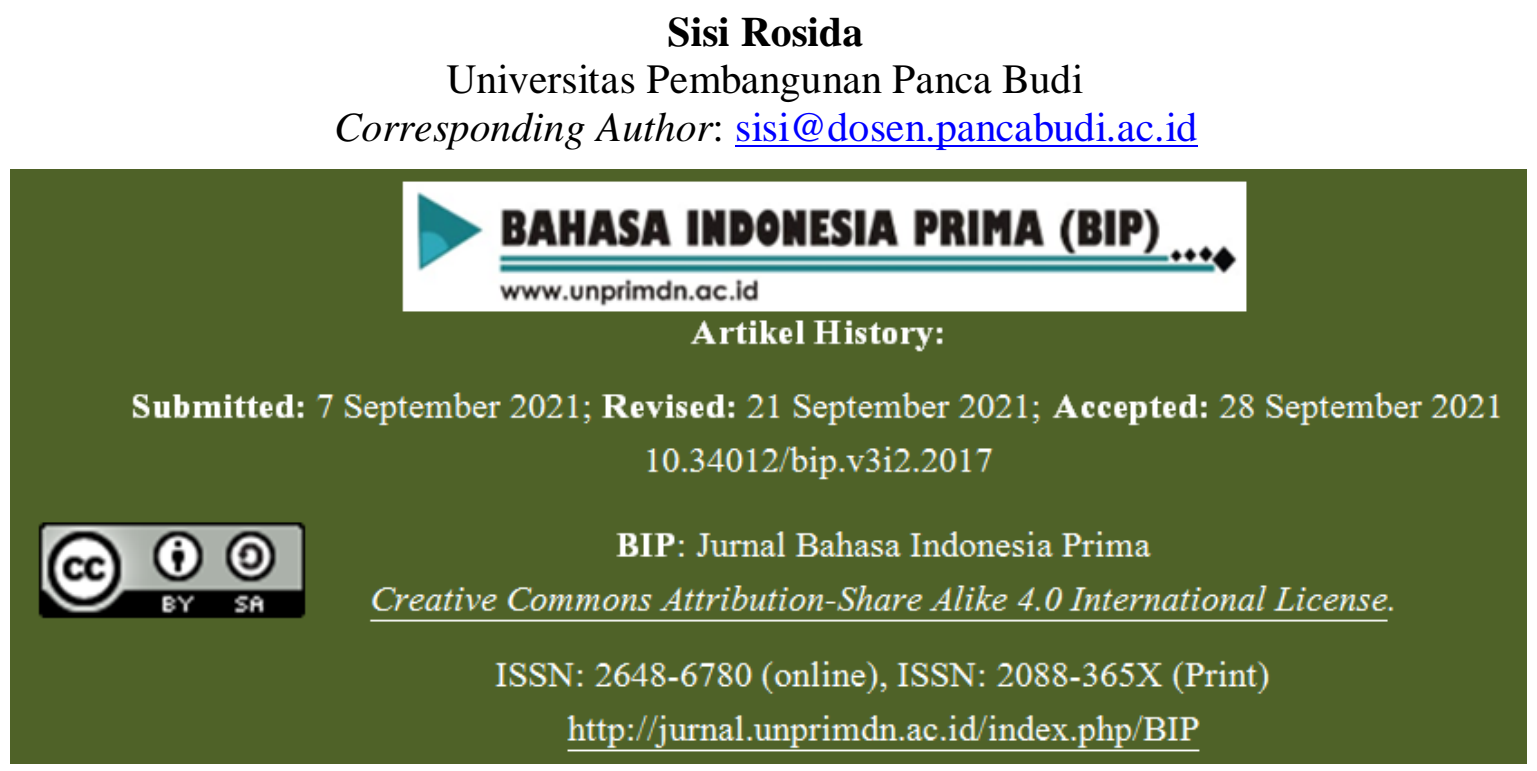

Abstrak-Komunikasi secara virtual memainkan peran penting di era digital. Situasi pandemi ini menuntut remaja berperan aktif dalam komunikasi virtual. Kurangnya kemampuan public speaking pada remaja di Forum Anak Medan (FAM), hal ini terlihat dari video inspiratif pada laman media sosial Dinas Pemberdayaan Perempuan, Perlindungan Anak, dan Pemberdayaan Masyarakat Kota Medan.Terlihat potensi kemampuan berbicara di depan umum remaja FAM yang berlum terarah secara maksimal. Kondisi ini terlepas dari menurunnya rasa kepercayaan diri remaja menghadapi perkembangan teknologi. Mengatasi masalah tersebut, diadakan pelatihan yang bertujuan untuk memaksimalkan kemampuan public speaking secara virtual dengan konten edukatif dengan bantuan aplikasi TikTok. Metode yang digunakan dalam pelatihan ini adalah ceramah, diskusi, dan demonstrasi.Angket digunakan sebagai tolak ukur ketercapaian kegiatan.Hasil pelatihan menunjukan bahwa aplikasi TikTok dapat dijadikan alternatif dalam meningkatkan kemampuan public speaking, hal ini menambah kreativitas remaja FAM dalam menghasilkan konten edukatif yang bermanfaat.Selama kegiatan remaja FAM berperan aktif dalam pelatihanpublic speaking virtualdengan sangat baik.Hal ini diketahui dari hasil angket sebesar 88\% peserta memahami teknik berkomunikasi virtual. Keaktivan para remaja diimplikasikan padalaman media sosial TikTok mereka yang menggunggah konten edukatif yang bermanfaat dengan empat tema, yakni: (1) life hack, (2) Tips do-it-your-self (3) memasak, dan (4) informasi inspiratif dengan kemampuan public speaking yang bagus.

Kata Kunci: pelatihan, keterampilan, public speaking,konten edukatif, aplikasi tiktok

ABSTRACT - Virtual communication plays a vital role in the digital era. This pandemic situation requires teenagers to play an active role in virtual interaction. The lack of public speaking skills occurs among members of Forum Anak Medan (FAM) (English: Medan Youth Forum). This can be seen from the inspirational video on the social media page of Women's 
Empowerment, Child Protection, and Community Empowerment Service of Medan. In the video, their potential for public speaking abilities is not yet fully focused. This condition cannot be separated from their decreased self-confidence facing technological developments. To overcome this problem, the researcher held training aiming at maximizing virtual public speaking skills with educational content using the TikTok application. The applied methods were lecturing, discussions, and demonstrations. Besides, the researcher used questionnaires for measuring the achievement of activities. Results showed that the TikTok application can be used as an alternative in improving public speaking skills, in which the application increased the creativity of members of FAM in producing useful educational content.During the activities, they played an active role in the virtual public speaking training very well. It was indicated by the scores of the questionnaire that was 88\%, meaning that participants understood virtual communication techniques.Their activities were applied on their personal TikTok account, in which they uploaded useful educational content with good public speaking skills, focusing on four themes: (1) life hacks, (2) do-it-yourself tips, (3) cooking, and (4) inspirational information.

Keywords: training, skills, public speaking, educational content, tiktok application

\section{A. Pendahuluan}

Public Speaking merupakan salah satu keterampilan yang harus dimiliki di era global ini. Kemampuan berbicara di depan umum terbentuk melalui proses belajar sejak masa pertumbuhan dari kecil hingga dewasa. Lingkungan, pengalaman, dan pola asuh orang tua turut memberikan pengaruh yang signifikan terhadap kemampuan berbicara di depan umum. Selain itu kemampuan berbicara di depan umum harus terus dilatih agar berkembang lebih maksimal. Keterampilan berbicara termasuk salah satu hal penting yang harus dilatih di masa anak-anak, remaja, hingga dewasa.

Manfaat publik speaking di kalangan remaja adalah agar mereka bisa tumbuh menjadi pribadi yang percaya diri, berani, dan kreatif. Tujuan utama berbicara adalah agar dapat menyampaikan pikiran secara efektif, dan pembicara dapat memahami makna segala sesuatu yang ingin dikomunikasikan. Pada dasarnya berbicara mempunyai tiga tujuan umum, yaitu memberitahukan dan melaporkan (to inform), menjamu dan menghibur (to entertain), membujuk, mengajak, mendesak, dan meyakinkan (to persuade)(Annisa et al., 2021).

Melihat banyaknya kasus remaja yang pasif dalam kemamuan public speaking sering terjadi di masyarakat, Dinas Pemberdayaan Perempuan, Perlindungan Anak, dan Pemberdayaan Masyarakat Kota Medan menciptakan wadah bagi anak-anak muda, khususnya remaja melalui Forum Anak Medan (FAM) untuk menemukan bakat dan potensi yang akan berguna di masa depan. Salah satu hal yang menjadi prioritas adalah keterampilan public speaking di era digital. Jika selama ini kita beranggapan bahwa keahlian tersebut hanya digunakan di depan khalayak, namun public spaking berkembang secara virtual melalui konten edukasi.

Masa pandemi membatasi ruang gerak masyarakat. Penyelenggaraan webinar dan pertemuan virtual di platform digital seperti zoom pun telah menjadi norma baru di era new normal. Hal ini membuat generasi millennial perlu menyesuaikan diri.Banyaknya pertemuan melalui event- 
event virtual di berbagai situasi baik formal maupun informal, mengharuskan remaja untuk dapat mengasah kemampuan berbicara secara virtual.

Saat ini, public speaking era 5.0 adalah memanfaatkan perkembangan teknologi untuk menyampaikan gagasan dengan tepat dan ringkas, di mana kita dapat menyampaikan ide secara virtual dengan memanfaatkan teknologi sebagai medianya. Komunikator dituntut bagaimana mengartikulasikan vokal, verbal, dan visual ini agar berdampak efektif kepada audiens digital. Sebuah ide apabila disampaikan secara efektif dapat mendorong kemampuan berbicara di depan umum merupakan salah satu kunci meraih kesuksesan di masa mendatang. Pasalnya, dengan kemampuan berbicara di hadapan umum yang baik, seseorang dapat meyakinkan ide dan gagasannya kepada orang lain.

Pembentukan Sumber Daya Manusia (SDM) yang berkualitas merupakan langkah mutlak yang harus dilakukan guna menghadapi tantangan era industri 5.0.Tak hanya mengandalkan kemampuan akademis, kualitas SDM generasi muda Indonesia juga perlu didongkrak melalui berbagai keterampilan lunak atau soft skills guna meningkatkan kecerdasan emosional. Salah satu soft skills penting ialah public speaking, yang akan memudahkan generasi muda dalam menyampaikan visi dan gagasannya kepada pengikutnya(Dwyr et al, 2018).

Ditambah lagi dengan pesatnya teknologi seperti saat ini di mana kita dapat menyampaikan ide, gagasan dan solusi terhadap sebuah masalah secara virtual, tanpa perlu bertatap muka langsung. Dengan kemudahan teknologi dan kemampuan public speaking yang mumpuni, apa yang kita sampaikan harus dipahami dengan tepat.

Tujuan utama pemberian materi "Public Speaking dalam konten edukatif" ini ialah guna melatih generasi muda dalam berbicara di depan umum secara daring. Khususnya, untuk menumbuhkan kepercayaan diri dan mampu menyampaikan ide dan gagasannya dengan baik di tengah masyarakat digital. Diharapkan, soft skills ini dapat mendorong generasi muda berkontribusi lebih dalam memanfaatkan media sosial ke arah yang positif (Rimawan et al., 2018).

Selain itu, seiring perkembangan teknologi, kita juga harus mempelajari cara menyampaikan ide dan gagasan di depan umum baik secara langsung (tatap muka) maupun secara tidak langsung (virtual), sehingga ide dan gagasan yang dimiliki dapat ditelaah dan diterima dengan baik.

Aplikasi TikTok sebagai media sosial primadona di kalangan remaja. TikTok juga dapat digunakan untuk membuat konten kreatif, salah satunya konten berbasis pengetahun atau edukasi. Aplikasi ini telah berkolaborasi dengan Ikatan Guru Indonesia (IGI) dan Jaringan Sekolah Digital Indonesia (JSDI) untuk menghasilkan konten edukasi. Aplikasi ini dipilih karena memahami bahwa mayoritas anak muda mengonsumsi berita secara online(Setianingrum et al., 2019).

Mencermati paparan diatas maka perlu diadakan Pelatihan Public Speaking bagi para remaja Forum Anak Medan di Dinas Pemberdayaan Perempuan, Perlindungan Anak, dan Pemberdayaan Masyarakat Kota Medan untuk melatih kemampuan public speaking dalam konten kreatif memanfaatkan aplikasi TikTok.Dengan diadakannya pematerian kepada masyarakat ini diharapkan dapat menjadi 
BIP: Jurnal Bahasa Indonesia Prima Vol. 3, No. 2, 2021, September 2021, PP.

kegiatan bermanfaat bagi para para remaja Forum Anak Medan agar mereka dapat memiliki wawasan yang lebih.terbuka dan luas serta dapat meningkatkan pengetahuan dan keterampilan dalam hal berbicara dan berkomunikasi dengan baik di depan umum. Selain tujuan diatas, melalui pengabdian kepada masyarakat ini juga diharapkan dapat terjadi hubungan positif yang berkelanjutan antara Pembangunan Panca Budi dengan Dinas Pemberdayaan Perempuan, Perlindungan Anak, dan Pemberdayaan Masyarakat Kota Medan, terutama dengan Forum Anak Medan (FAM).

\section{B. Metode Penelitian}

Adapun metode pendekatan yang ditawarkan oleh pelaksana pematerian kepada masyarakat, yaitu: (1) Ceramah dan diskusi merupakan cara yang dipakai pelaksana pematerian masyarakat dengan memakai metode $50 \%$ berupa teori dan $50 \%$ berupa praktek langsung dengan para Remaja FAM (Forum Anak Medan). Bahan ceramah (modul) pelatihan diberikan pada peserta, setelah selesai ceramah dilanjutkan dengan diskusi (tanya jawab) tentang hambatan yang dihadapi oleh para remaja dalam menerapkan public speaking dan pembuatan konten edukatif.

(2) Diskusi dan demonstrasi "Pelatihan Keterampilan Public Speaking dalam Konten Edukatif melalui Aplikasi Tiktok pada Remaja FAM (Forum Anak Medan) di Dinas Pemberdayaan Perempuan, Perlindungan Anak, dan Pemberdayaan Masyarakat Kota Medan”. Praktek langsung membuat membuat konten edukatif dengan menerapkan keterampilan public speaking yang baik memahami dan menguasai materi yang sudah dijelaskan sebelumnya.

\section{Hasil dan Pembahasan}

Kegiatan Pengabdian kepada masyarakat dosen Universitas Pembangunan Panca Budi dilaksanakan dimulai tanggal 13, 16, dan 18 Agustus 2021 yang berlangsung selama 3 pertemuan. Pada setiap pertemuannya dibagi menjadi 2 sesi.Peserta pelatihan berjumlah 40 orang, selurunya adalah anggota Remaja Forum Anak Medan (FAM).Kegiatan dimulai dari pukul 09.00 sampai pukul 11.00, bertempat di Jl. Jendral Besar AH Nasution No.112.

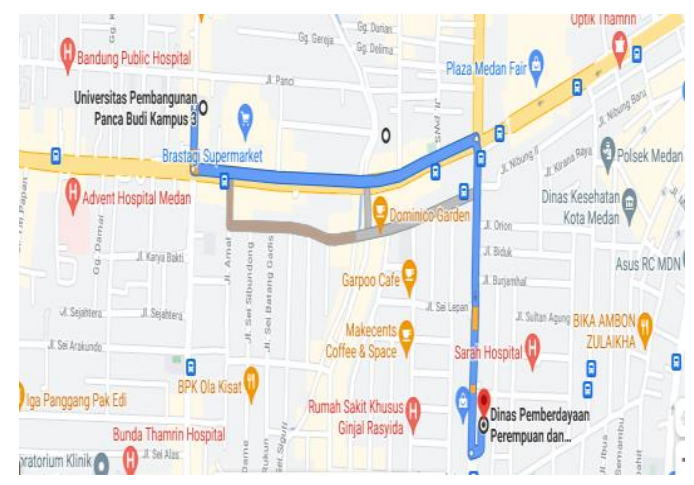

Gambar 1. Lokasi dari Kampus ke Lokasi Pematerian

Pertemuan pertama, dilaksanakan pada hari jumat tanggal 13 Agustus 2021.Pertemuan ini dibagi menjadi 2 sesi dimana masing-masing sesi terdiri dari 60 menit. Pada sesi pertama, pemateri memperkenalkan diri dan memberikan games untuk menghibur. Hal ini dilakukan untuk mencairkan suasana dan menambah keakraban. Di sesi ini pula lembaran materi dibagikan beserta alat tulis bagi peserta. Kemudian, pada sesi kedua peserta diarahkan untuk mengisi kuisioner dengan pertanyaan seputar public speaking.

Dari kuisioner yang dibagikan kepada peserta, diperoleh jawaban yang dominan. Pertanyaan seperti mereka memiliki rasa tidak percaya diri dan tegang apabila harus berbicara di depan umum. Kemudian mereka juga hanya mengetahui dasar-dasar Public Speaking tanpa tahu komponen- 
komponen lain di dalamnya.Mereka juga awam pada istilah-istilah khusus dalam Public Speaking.Mereka bahkan tidak mengetahui bahwa untuk dapat berbicara di depan umum, bahasa tubuh, variasi vocal dan artikulasi juga perlu dipelajari.

Selanjutnya para peserta diberikan praktik singkatberupa "self introduction virtual", pengenalan singkat mengenai diri mereka dengan durasi waktu maksimal 1 menit melalui aplikasi TikTok. Hal ini dilakukan guna mengetahui kemampuan awal public speaking para peserta sebelum mereka diberikan materi pelatihan.

Dari penampilan peserta, terlihat sebagian besar masih malu-malu untuk berbicara di depan kamera. Dalam hal ini pemilihan kata yang digunakan para remaja masih terbatas.Seluruh peserta terlihat kaku dan kesulitan dalam mengendalikan emosi dan ketegangan mereka.Hal ini terlihat saat melakukan presentasi secara virtual. Beberapa remaja terlihat gemetar, bicara terpatah-patah, mengulang kata-kata, dan minim ekspresi. Beberapa diantaranya bahkan sama sekali tidak berani mempresentasikan diri mereka secara virtual, hal ini dikarenakan alasan takut dan malu.

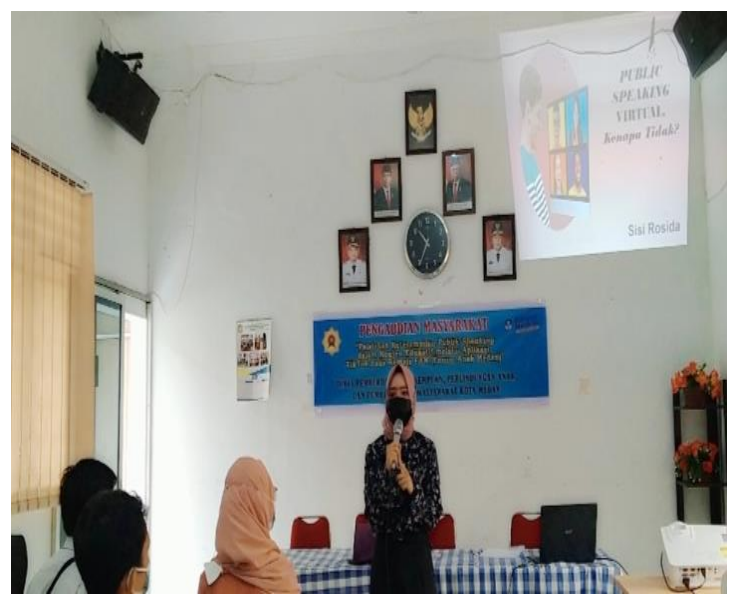

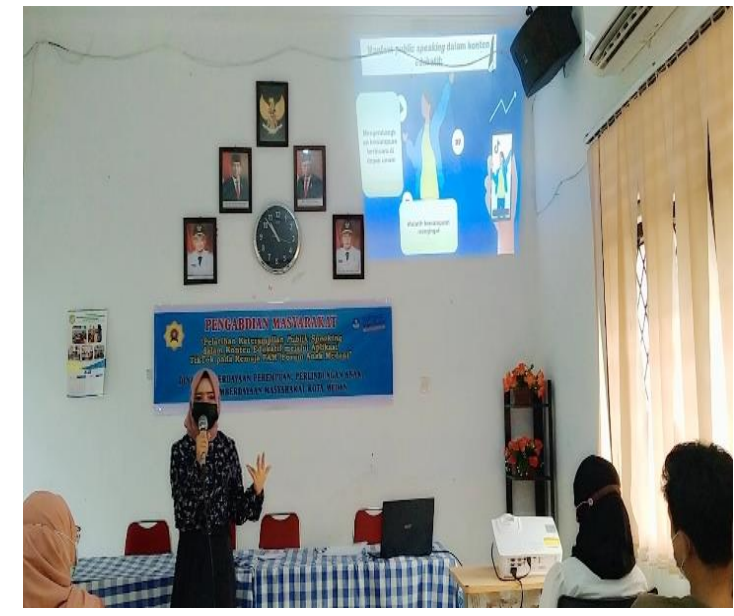

Gambar 2. Pemberian Materi Public Speaking Virtual

Hal menarik terjadi ketika seorang peserta menayangkan video perkenalan dirinya, beberapa temannya merasa lucu kemudian bersorak dan tertawa. Begitupula peserta dengan giliran tampil selanjutnya, ia terlihat sama tegang dan ragu untuk menayangkan hasil video public speaking. Hal tersebut sangat wajar karena sebelumnya para remaja tidak pernah mengikuti pelatihan Public Speaking Virtual. Walaupun demikian, beberapa remaja sangat percaya diri dalam menunjukkan konten yang ia buat. Dalam konten tersebut terlihat peserta sangat santai dan bagus dalam memperkenalkan diri, hal tentunya menambah motivasi bagi peserta pelatihan lainnya.

Banyaknya peserta siap-sikap peserta pelatihan yang muncul, seperti: gugup, bingung, malu, dan tidak siap untuk berbicara di depan kamera. Mereka menyadari bahwa pentingnya pelatihan ini diikuti agar mereka memiliki kemampuan berbicara di depan umum secara virtual dengan baik, mengingat teknologi yang semakin berkembang mengharuskan mereka belajar berkomunikasi sistem daring. Hal inilah yang menambah antusias remaja FAM untuk mengikuti pelatihan sampai selesai. 
Di akhir pertemuan, pemateri menyampaikan temuan yang didapatkan dari hasil presentasi kemudian memberikan pengarahan mengenai kekurangan dan kelebihan masing-masing peserta.Pemateri juga menyampaikan bahwa setelah pelatihan ini selesai dilaksanakan, maka akan diadakan evaluasi kembali dan hasil evaluasi di awal akan dibandingkan dengan evaluasi akhir. Tentunya para pemateri berharap adanya perubahan dan kemajuan dari setiap peserta setelah pematerian ini selesai

Pada pertemuan Kedua, pelaksanaannya pada hari Senin, 16 Agustus 2021. Sesi pertama, diisi dengan materi yang disampaikan oleh ibu Sisi Rosida, S.Pd., M.Pd. sebagai pemateri tunggal dengan tema public speaking virtual. Adapun materi yang disampaikan, yaitu: (1) Public speaking di era digital sangat dibutuhkan, banyaknya platform jejaring sosial di era digital mulai dari facebook, twitter, instagram, likedIn, dan TikTok yang memiliki fungsi masingmasing dalam menyampaikan informasi. (2) Konten edukatif dan manfaat viewersnya, bahwa nonverbal communication berkontribusi $70 \%$ lebih banyak daripada mulut kita, sehingga gesture tubuh sangat berperan di menit pertama berkomunikasi dengan orang atau 'first impression'. (3) TikTok sebagai konten kreatif. Dalam komunikasi digital memiliki peran penting di era modern saat ini.Kecanggihan teknologi tidak hanya menuntut kita untuk berkomunikasi secara langsung, namun mengharuskan kita untuk tampil dalam komunikasi virtual. Adaptasilah sebagai kunci dalam beraktivitas di masa pandemi yang memanfaatkan teknologi jarak jauh. Hal ini dikarenakan kegiatan yang tidak dapat dilakukan secara normal karena harus mengikuti protokol kesehatan yang ditetapkan. Hal ini membuat masyarakat beralih mencoba menggunakan komunikasi secara virtual.

Menyikapi tantangan digital yang cukup sulit ini, sebagian besar peserta merasakan keanehan. Sebab, dalam public speaking virtual seakan-akan pembicara bertutur dengan benda mati seperti laptop/computer, camera, dan telepromter

Hal ini mengakibatkan peserta lupa ide/gagasan, banyak pembicara mendadak kurang percaya diri, komunikasi yang terbata-bata, serta hilang fokus karena tidak bisa melihat audiens secara langsung.

Menyikapi hal ini, ada beberapa cara yang harus diperhatikan dalam melakukan public speaking secara virtual, yaitu: (1) Menghadap kamera dan menyesuaikan kontak mata. Secara umum, komunikasi secara langsung tidak jauh berbeda dengan komunikasi virtual. Komunikasi secara digital ini mengharuskan kita untuk melakukan "eye contact atau kontak mata," pada lawan bicara.Lawan bicara yang dimaksud adalah kamera laptop atau ponsel.Kamera diibaratkan sebagai audiens. Dengan melihat kamera, sama artinya kita menghormati audiens. (2) Artikulasi dan tempo bicara.

Selain fokus pada kamera saat berkomunikasi, melatih diri untuk berbicara dengan baik dan benar sangat diperlukan.Hal ini dapat diupayakan dengan mengatur artikulasi dan tempo bicara agar mudah dipahami audiens. Pastikan tempo bicara tidak terlalu lambat maupun terlalu cepat, artikulasi bicara dalam keadaan jelas. Beberapa hal ini sangat penting untuk diperhatikan sebab saat meakukan public speaking diharuskan memahami bahwa adanya perbedaan antara gerak bibir dan layar yang sering disebut sebagai buffer atau 
lag. Maka, dibutuhkan kejelasan dalam berbicara dengan volume yang sedang agar audiens memahaminya.

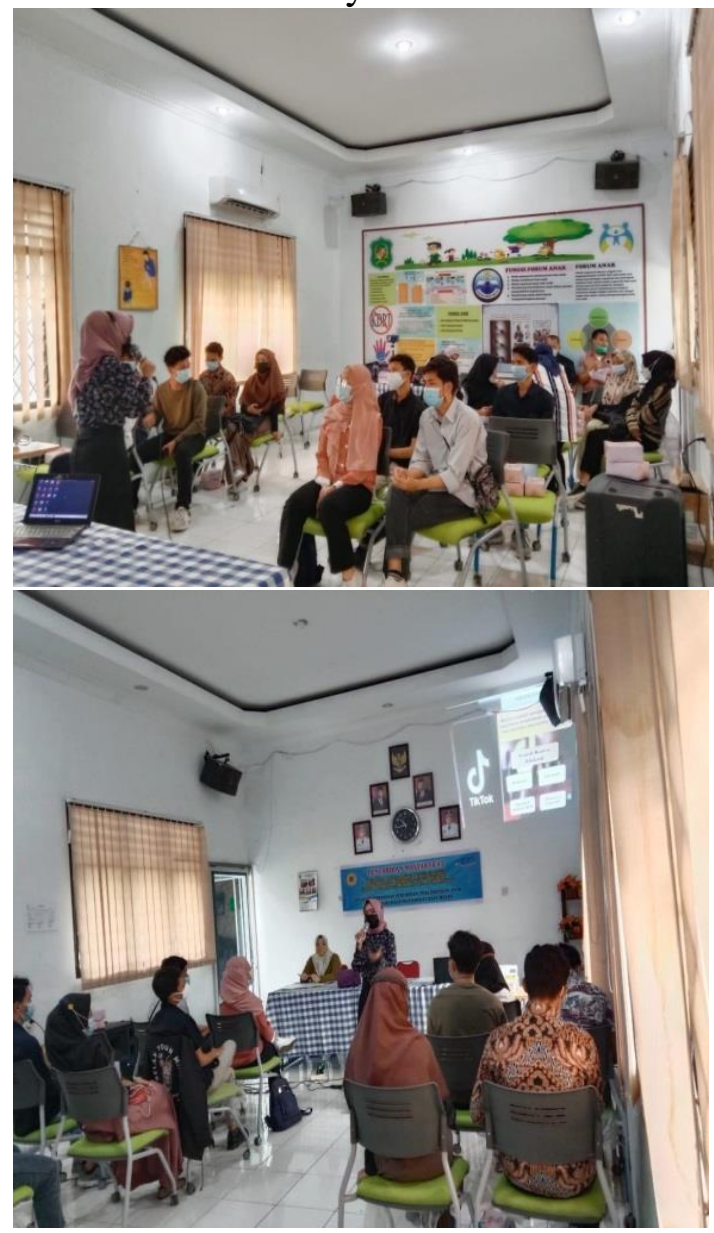

Gambar 3. Pelatihan pada materi Konten Speaker

Pada pertemuan selanjutnya yaitu pertemuan ketiga. Pada Hari Rabu, 18 Agustus 2021 Sesi Pertama, pelatihan difokuskan pada Materi Konten Speaker dan berdiskusi dengan para peserta. Di sesi ini pula para pemateri memberikan arahan dan ketentuan untuk praktik akhir yang dilaksanakan pada pertemuan ke-empat atau pertemuan terakhir.

Pendidikan berbasis digital bagian yang paling kompleks dalam keseluruhan kerangka edukasi guna pembelajaran yang kreatif. Media TikTok secara efektif mengoptimalkan pembelajaran menarik yang menyediakan pengalaman belajar yang menarik dan mudah diingat. Kolaborasi belajar melalui TikTok, peserta dapat mengunggah video dengan durasi 15 detik sampai 60 detik berbantuan program editing sederhana untuk membuat konten edukatif. Edukasi diartikan sebagai proses pembelajaran yang dilakukan baik secara formal maupun non formal, hal ini bertujuan untuk mendidik, memberikan ilmu pengetahuan, serta mengembangkan potensi diri yang ada dalam diri setiap manusia, kemudian mewujudkan proses pembelajaran tersebut dengan lebih baik. Berikut beberapa hal-hal yang harus dipahami konten speaker untuk beredukasi melaui TikTok, yaitu: (1) Konten Ringkas, memberikan pembelajaran yang efektif dan tidak bertele-tele dimana isi, penjelasan, dan sasaran yang jelas.(2) Mengemas Konten Menarik, artinya dengan memberikan visual/gambar dan audio yang bagus. Hal ini akan mencegah konten bersifat monoton. (3) Mudah dipahami, memberikan bahasa yang bersahabat, lugas, dan jelas agar memudahkan orang lain untuk memahaminya. (4) Menampilkan Keilmiahan, konten dinilai lebih akurat apabila memiliki hasil data penelitian atau analisis ahli dalam bidangnya., sehingga konten bersifat valid. Pada sesi ini banyak sekali pertanyaan-pertanyaan yang muncul seputar teknis presentasi dan sistem penilaian.

Sesi kedua, peserta melakukan simulasi public speaking secara virtual dan di sesi ini mereka mengerahkan segala kemampuan mereka dan ditambah dengan pengetahuan yang telah mereka dapatkan melalui pelatihan Public Speaking di pertemuan sebelumnya. Sebagai penutup acara pelatihan ini, pemateri kembali mengevalusai penampilan peserta.

Pada sesi ini, disampaikan bahwa maksud pelatihan ini adalah untuk merangsang ide kreatif peserta dalam 
memberikan konten yang edukatif di media sosial.Adapun konten edukasi yang dimaksudkan dimana pembelajaran yang diberikan bermanfaat bagi masyarakat luas.

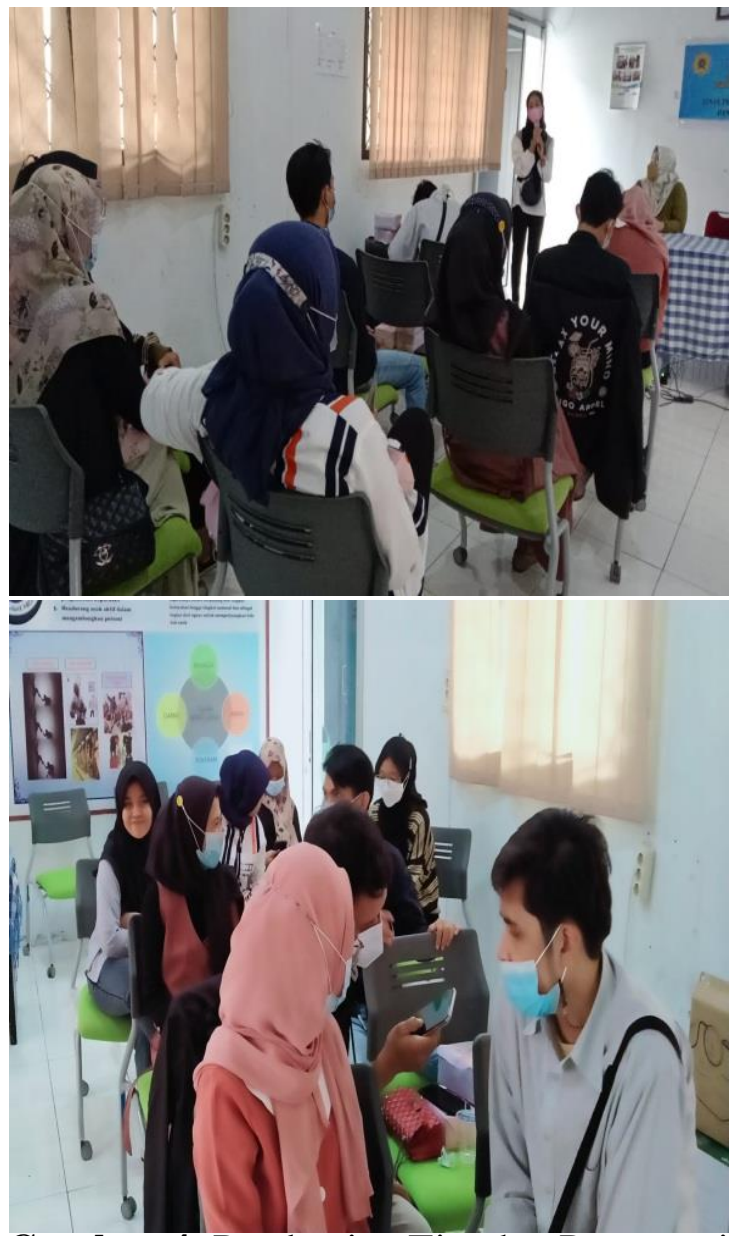

Gambar 4. Pembagian Tim dan Presentasi Konten Edukatif

Peserta dibagi ke dalam 4 (empat) tim. Tim pertama mengambil tema life hack, sementara tim kedua mengangkat tema Tips Do-it-Your-Self, tim ketiga dengan tema memasak, dan tim keempat merujuk tema informasi inspiratif. Semua tim dibantu oleh pemateri untuk saling bekerja sama dengan tugasnya. Para peserta diberikan waktu sekitar 30 (tiga puluh) menit untuk menyelesaikan rancangan konten mereka. Seluruh tim menulis ide konten di atas kertas yang sudah dipesiapkan. Setelah mendapatkan ide, seluruh tim mempresentasikan hasil rancangan mereka secara bergantian.
Setelah semua peserta diberikan pelatihan selama beberapa sesi, terlihat peningkatan dan kepercayaan diri mereka peserta. Hal diketahui dari cara konten yang merka hasilkan dan kemampuan public speaking peserta. Hal ini diharapkan dapat diaplikasikan dalam kehidupan sehari-hari untuk mengunggah konten yang bermanfaat.Bahkan beberapa peserta mengatakan mereka lebih percaya diri dan ingin berbagi hal-hal positif di sosial media.

Sejak hari pertama, pelatihan ini mendapat respon yang sangat baik dari seluruh peserta.Selama pelatihan, peserta selalu datang tepat waktu dan sangat antusias dalam mendengarkan penjelasan dari para pemateri. Para peserta juga sangat aktif dalam sesi diskusi dan banyak pertanyaan-pertanyaan yang dilontarkan. Mereka sangat menyadari bahwa kemampuan Public Speaking sangat bermanfaat bagi mereka, tidak hanya untuk kehidupan sehari-hari mereka tapi juga untuk membantu meningkatkan kemampuan melakukan presentasi di sekolah mereka.

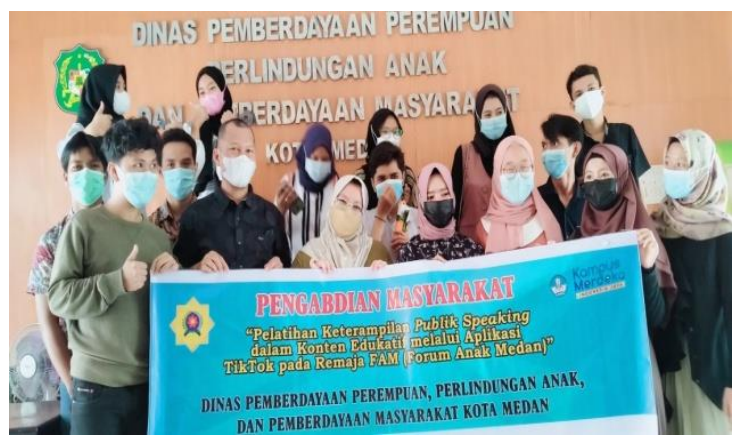

Gambar 5. Foto bersama dengan Remaja FAM dan Dinas

Pada sesi ini dipaparkan hasil evaluasi di awal pelatihan dan akhir pelatihan serta hasil kuisioner yang telah diisi oleh peserta pelatihan. Angket diberikan melaui google form kepada remaja FAM digunakan untuk mengetahui persentase keberhasilan pelatihan public speaking dalam konten 
edukatif melalui aplikasi TikTok. Dari angket yang telah dibagikan diperoleh hasil $88 \%$ remaja FAM memamhami materi pelatihan. Maka, dapat diarik kesimpulan bahwa aplikasi Tiktok sebagai alternatif meningkatkan kemampuan public speaking dalam konten edukatif.

\section{Simpulan}

Komunikasi secara virtual memainkan peran penting di era digital.Situasi pandemi ini menuntut remaja berperan aktif dalam komunikasi virtual. Saat ini, public speaking era 5.0 adalah memanfaatkan perkembangan teknologi untuk menyampaikan gagasan dengan tepat dan ringkas, di mana kita dapat menyampaikan ide secara virtual dengan memanfaatkan teknologi sebagai medianya. Melihat banyaknya kasus remaja yang pasif dalam kemamuan public speaking sering terjadi di masyarakat, maka perlu diadakan Pelatihan Public Speaking bagi para remaja Forum Anak Medan di Dinas Pemberdayaan Perempuan, Perlindungan Anak, dan Pemberdayaan Masyarakat Kota Medan untuk melatih kemampuan public speaking dalam konten kreatif memanfaatkan aplikasi TikTok. Kegiatan Pengabdian kepada masyarakat dilaksanakan dimulai pada hari Jumat, 13 Agustus 2021 yang berlangsung selama 3 pertemuan. Pada setiap pertemuannya dibagi menjadi 2 sesi, dari pukul 09.00 sampai pukul 11.00.Pada sesi pertama, pemateri memperkenalkan diri dan memberikan games untuk menghibur. Kemudian, pada sesi kedua peserta diarahkan untuk mengisi kuisioner dengan pertanyaan seputar public speaking.

Selanjutnya para peserta diberikan praktik singkatberupa "self introduction virtual", pengenalan singkat mengenai diri mereka dengan durasi waktu maksimal 1 menit melalui aplikasi TikTok. Pada pertemuan Kedua, pelaksanaannya pada hari Senin, 16 Agustus 2021.Sesi pertama, diisi materi dengan tema public speaking virtual, dan sesi kedua sebagai praktik singkat. Pada pertemuan selanjutnya yaitu pertemuan ketiga. Pada Hari Rabu, 18 Agustus 2021 Sesi Pertama, pelatihan difokuskan pada Materi Konten Speaker dan berdiskusi dengan para peserta. Di sesi ini pula para pemateri memberikan arahan dan ketentuan untuk praktik akhir yang dilaksanakan pada pertemuan ke-empat atau pertemuan terakhir.Sesi kedua, peserta melakukan simulasi public speaking secara virtual dan di sesi ini mereka mengerahkan segala kemampuan mereka dan ditambah dengan pengetahuan yang telah mereka dapatkan melalui pelatihan Public Speaking di pertemuan sebelumnya. Sebagai penutup acara pelatihan ini, pemateri kembali mengevalusai penampilan peserta. Dari angket yang telah dibagikan diperoleh hasil $88 \%$ remaja FAM memamhami materi pelatihan. Maka, dapat diarik kesimpulan bahwa aplikasi Tiktok sebagai alternatif meningkatkan kemampuan public speaking dalam konten edukatif.

\section{Daftar Pustaka}

Anderson, P. L., Zimand, E., Hodges, L. F., \& Rothbaum, B. O. (2005). Cognitive behavioral therapy for public-speaking anxiety using virtual reality for exposure. Depression and anxiety, 22(3), 156158.https://doi.org/10.1002/da.200 90.

Annissa, J., \& Putra, R. W. (2021).Pelatihan Public Speaking dalam Meningkatkan Kepercayaan Diri Siswa Pkbm Bakti Asih 
BIP: Jurnal Bahasa Indonesia Prima Vol. 3, No. 2, 2021, September 2021, PP.

Ciledug Tangerang. BERNAS:

Jurnal Pengabdian Kepada

Masyarakat, 2(2),

619-

623.https://doi.org/10.31949/jb.v2i

$\underline{2.1031}$

Beebe, S. A., \& Beebe, S. J. (2010). Public speaking handbook.Allyn \& Bacon.

Clark, R. A., \& Jones, D. (2001).A comparison of traditional and online formats in a public speaking course. Communication

Education, 50(2), 109-124. https://doi.org/10.1080/036345201 09379238

Coopman, S. J., \& Lull, J. (2014). Public speaking: The evolving art. Cengage Learning.

Crick, N. (2017). Rhetorical public speaking: Civic engagement in the digital age. Routledge.

Davidson, C. N., Goldberg, D. T., \& Jones, Z. M. (2010). The future of thinking: Learning institutions in a digital age. The MIT Press.

Dwyer, K. K., \& Davidson, M. M. (2012). Is public speaking really more feared than death?. Communication Research Reports, 29(2), 99-107. https://doi.org/10.1080/08824096.2 012.667772.

Hancock, A. B., Stone, M. D., Brundage, S. B., \& Zeigler, M. T. (2010). Public speaking attitudes: does curriculum make a difference?. Journal of voice, 24(3), 307.https://doi.org/10.1016/j.jvoice .2008.09.007.

Harris, S. R., Kemmerling, R. L., \& North, M. M. (2002).Brief virtual reality therapy for public speaking anxiety. Cyberpsychology \& behavior, 5(6), 543550.http://doi.org/10.1089/1094931 02321018187.

Jaffe, C. (2015). Public speaking: Concepts and skills for a diverse society. Cengage Learning.

Koch, A., \& Schmitt, J. (2018). Purposeful Communication in a Digital Age: Speaking for Success. Routledge.

Lucas, S. E. (2009). The art of public speaking 11th edition. Boston. Mc. Graw Hill.

Pertaub, D. P., Slater, M., \& Barker, C. (2002).An experiment on public speaking anxiety in response to three different types of virtual audience. Presence, 11(1), 68-78. 10.1162/105474602317343668.

Rimawan, P. (2018). Sistem Realitas Virtual untuk Berlatih Berbicara di Depan Umum Berbasis Video 360 dan Sensor Detak Jantung (Doctoral dissertation, Institut Teknologi Sepuluh Nopember).

Setianingrum, V. M. (2019).Komunikasi Pembelajaran melalui Virtual Learning. Translitera: Jurnal Kajian Komunikasi dan Studi Media, 8(02), 44- 
BIP: Jurnal Bahasa Indonesia Prima Vol. 3, No. 2, 2021, September 2021, PP.

54.https://doi.org/10.35457/translit era.v8i02.926

Soegijono, J. C., Yudani, H. D., \&

Wirawan, I. G. N. (2020).Perancangan Virtual Reality Sebagai Media untuk Meningkatkan Kepercayaan Diri di Atas Panggung. Jurnal DKV Adiwarna, 1(16), 10.

Verderber, R. F., Sellnow, D. D., \& Verderber, K. S. (2014). The challenge of effective speaking in a digital age. Cengage Learning. 